\title{
PENGARUH MODEL DISCOVERY LEARNING BERBASIS KONTEKSTUAL TERHADAP KEMAMPUAN PEMAHAMAN KONSEP MATEMATIKA SISWA KELAS VII SMP NEGERI 2 BAROMBONG
}

\author{
Fanisa Septarini Ahmad ${ }^{1}$ \\ Ilham Minggi ${ }^{2}$ \\ Erni Ekafitria Bahar ${ }^{3 *}$ \\ ${ }^{1,3}$ Prodi Pendidikan Matematika, Universitas Muhammadiyah Makassar, Indonesia \\ ${ }^{2}$ Universitas Negeri Makassar, Makassar, Indonesia
}

\begin{abstract}
Abstrak
Jenis penelitian ini adalah penelitian quasi eksperimen yang melibatkan dua kelas dengan desain penelitian Control Group Pretest-Posttest Design. Populasi pada penelitian ini adalah seluruh siswa kelas VII SMP Negeri 2 Barombong. Sampel pada penelitian ini dipilih 2 kelas secara random yakni kelas $\mathrm{VII}_{\mathrm{B}}$ sebagai kelas eksperimen dengan model Discovery Learning Berbasis Kontekstual dan kelas $\mathrm{VII}_{\mathrm{C}}$ dengan model konvensional. Instrumen penelitian ini adalah tes kemampuan pemahaman konsep matematika siswa. Hasil penelitian menunjukkan bahwa: (1) Hasil pretest kelas eksperimen menunjukkan kemampuan pemahaman konsep matematika siswa adalah 52,68 yang berada pada kategori Rendah. Sedangkan Hasil pretest kelas kontrol adalah 55,00 yang berada pada kategori Cukup Tinggi. (2) Hasil posttest kelas eksperimen adalah 80,35 yang berada pada kategori Tinggi. (3) Hasil uji t (Independent Sample t-test) terhadap data posttest pada kelas eksperimen dan kelas kontrol, diperoleh hasil bahwa kemampuan pemahaman konsep matematika siswa pada kelas eksperimen yang diajar dengan model Discovery Learning berbasis kontekstual lebih dari kemampuan pemahaman konsep siswa pada kelas kontrol yang diajar dengan model konvensional. Demikian pula dengan hasil analisis secara inferensial $N$-Gain pada kedua kelas, hasilnya menunjukkan bahwa peningkatan kemampuan pemahaman konsep matematika siswa yang diajar dengan model Discovery Learning berbasis kontekstual lebih dari peningkatan kemampuan pemahaman konsep siswa yang diajar dengan model konvensional. Berdasarkan hasil penelitian tersebut dapat disimpulkan bahwa penerapan model Discovery Learning berbasis kontekstual berpengaruh terhadap kemampuan pemahaman konsep matematika siswa pada kelas VII SMP Negeri 2 Barombong.
\end{abstract}

Kata Kunci: Matematika, Kemampuan Pemahaman Konsep, Model Konvensional, Model Discovery Learning Berbasis Kontekstual

\section{Pendahuluan}

Pendidikan pada dasarnya merupakan usaha manusia untuk meningkatkan ilmu pengetahuan, baik yang diperoleh melalui lembaga formal maupun informal yang diyakini mampu menanamkan kapasitas baru bagi semua orang untuk mempelajari pengetahuan dan keterampilan baru sehingga dapat diperoleh manusia produktif. Pendidikan Matematika sebagai salah satu bidang ilmu dalam dunia pendidikan juga merupakan salah satu bidang studi yang sangat penting. Matematika merupakan ilmu yang mendasari perkembangan teknologi modern, 
mempunyai peranan penting dalam berbagai disiplin ilmu dan memajukan daya pikir manusia.

Salah satu tujuan pembelajaran Matematika sebagaimana yang telah diuraikan dalam Permendikbud No. 59 Tahun 2014, yaitu agar peserta didik memiliki kemampuan memahami konsep Matematika, menjelaskan keterkaitan antar konsep dan mengaplikasikan konsep. Pemahaman terhadap konsep sangat penting karena apabila siswa menguasai konsep materi prasyarat maka siswa akan mudah untuk memahami konsep materi selanjutnya. Siswa yang memahami suatu konsep juga akan dapat menyelesaikan berbagai macam persoalan dan variasinya.

Berdasarkan hasil observasi dan wawancara dengan salah seorang guru mata pelajaran Matematika kelas VII SMP Negeri 2 Barombong, yang diperoleh informasi bahwa: (1) Siswa kurang memahami manfaat belajar Matematika dan kurang mampu menghubungkan materi/ konsep yang telah dipelajari dengan kehidupan nyata. Sehingga mereka berpendapat bahwa Matematika tidak terlalu berguna dalam kehidupan sehari-hari; (2) Cara belajar siswa yang mengacu pada keterampilan menyelesaikan soal-soal tanpa didukung oleh penguasaan atau memahami konsep secara mantap; (3) Strategi pembelajaran cenderung menggunakan alur memberikan informasi, memberikan contoh-contoh soal, latihan soal dan pemberian pekerjaan rumah; (4) Soal-soal pemecahan masalah yang berkaitan dengan bidang studi atau lingkungan sekitar masih kurang; (5) Siswa kurang mampu belajar mandiri, pembelajaran pada umumnya masih di dominasi oleh guru.

Untuk mengatasi permasalahan di atas, diperlukan penerapan suatu pendekatan maupun model pembelajaran yang menarik dan berpusat pada siswa yang mengaktifkan siswa mengkonstruksi materi pelajaran membuat siswa tidak hanya menghafal fakta-fakta saja, tetapi terdorong belajar melalui mengalami. Jika siswa diberikan kesempatan untuk menggunakan kemampuan pemahaman dan bernalarnya dalam memecahkan suatu permasalahan berdasarkan pengalamannya sendiri, maka siswa akan lebih mudah memahami konsep, mampu memodelkan masalah kedalam bentuk Matematika, dengan demikian pengetahuan siswa terhadap suatu materi akan lebih lama melekat dalam pikiran mereka. Salah satu pendekatan yang dirasa sesuai untuk mengatasi hal tersebut ialah pembelajaran secara kontekstual yang dijabarkan lebih lanjut kedalam model discovery learning. Menurut Komalasari (2010) Pendekatan pembelajaran kontekstual adalah pendekatan pembelajaran yang mengaitkan antara materi yang dipelajari dengan kehidupan nyata siswa sehari-hari, baik dalam lingkungan keluarga, sekolah, masyarakat maupun warga negara, dengan tujuan untuk menemukan makna materi tersebut bagi kehidupannya.

Pembelajaran kontekstual merupakan pendekatan dalam proses pembelajaran yang 
dalam kegiatannya materi pembelajaran dikaitkan dengan situasi dunia nyata yang dihadapi. Belajar akan lebih bermakna jika anak mengalami apa yang dipelajarinya, bukan sekadar mengetahui. Dengan kata lain pembelajaran akan bermakna dan menyenangkan apabila peserta didik diberi kesempatan untuk mengembangkan potensinya sendiri dalam menemukan suatu konsep dan prinsip dengan fasilitator guru yang professional. Menurut yamin (2013), komponen utama dalam pendekatan kontekstual adalah konstruktivisme, Inquiry (menemukan), questioning (bertanya), learning community (masyarakat belajar), modeling (pemodelan), reflection (refleksi), dan authentic assessment (penilaian yang sebenarnya). Pembelajaran kontekstual sebagai suatu pendekatan pembelajaran masih harus dijabarkan lebih lanjut ke dalam strategi atau model pembelajaran tertentu, sehingga mudah di praktikkan di sekolah. Penerapan pendekatan pembelajaran kontekstual dirasa cocok dikolaborasikan dengan model pembelajaran discovery learning.

Model discovery merupakan pembelajaran yang menekankan pada pengalaman langsung dan pentingnya pemahaman struktur atau ide-ide penting terhadap suatu disiplin ilmu, melalui keterlibatan siswa secara aktif dalam pembelajaran. Sani (2014) mengungkapkan bahwa discovery adalah menemukan konsep melalui serangkaian data atau informasi yang diperoleh melalui pengamatan atau percobaan. Dalam model discovery learning, siswa di dorong untuk berfikir sendiri, menganalisis sendiri, sehingga dapat menemukan prinsip umum berdasarkan bahan atau data yang telah disediakan oleh guru (Iriana, 2008). Pada model Discovery Learning siswa diharapkan mampu lebih aktif dengan mengolah informasi dan konsep-konsep matematika tersebut. Siswa juga mampu membuat kesimpulan dari materi pembelajaran yang telah diajarkan. Kurniasih dan Sani (2014) mengemukakan langkah-langkah operasional model discovery learning yaitu sebagai berikut:

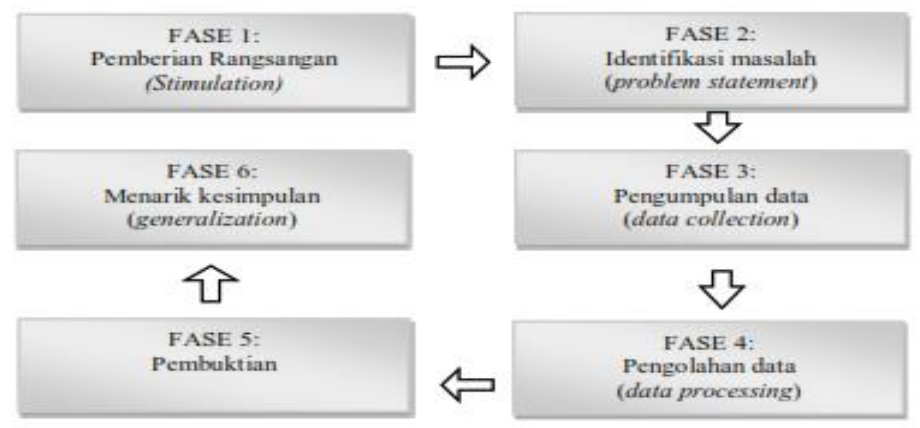

Gambar 1. Langkah Model Discovery Learning

Berdasarkan uraian diatas, peneliti bermaksud melakukan sebuah penelitian yang berjudul "Pengaruh Penerapan Model Discovery Learning Berbasis Kontekstual terhadap Kemampuan Pemahaman Konsep Matematika Siswa Kelas VII SMP Negeri 2 Barombong”. 
Adapun indikator pemahaman konsep menurut Kurikulum 2006 dalam Tim Pustaka Yustisia (2007) yaitu: (1) Menyatakan ulang konsep, (2) Mengklarifikasi objek-objek menurut sifat-sifat tertentu (sesuai dengan konsepnya), (3) Memberi contoh dan bukan contoh dari suatu konsep, (4) Menyajikan konsep dalam berbagai bentuk representasi matematika, (5) Mengembangkan syarat perlu atau syarat cukup dari suatu konsep, (6) Menggunakan dan memanfaatkan serta memilih prosedur atau operasi tertentu, dan (7) Mengaplikasikan konsep atau algoritma dalam pemecahan masalah.

\section{Metode Penelitian}

Penelitian ini merupakan penelitian eksperimen semu yang terdiri dari satu perlakuan (treatment) dan satu variabel terikat. Perlakuan yang diberikan adalah model pembelajaran yaitu model pembelajaran discovery learning berbasis kontekstual dan pembelajaran konvensional, sedangkan variabel terikatnya adalah pemahaman konsep matematika siswa. Desain yang digunakan adalah Control Group Pretest-Posttest Design yang melibatkan dua kelompok yaitu kelompok eksperimen dan kelompok kontrol. Pada kedua kelompok baik eksperimen maupun kontol diberikan pretest sebelum diberikan perlakuan (treatment) kemudian diberikan posttest setelah diberikan perlakuan (treatment).

Penelitian ini dilakukan di SMP Negeri 2 Barombong, Kabupaten Gowa dengan populasi penelitian adalah seluruh siswa kelas VII pada semester genap tahun ajaran 2018/2019. Dalam Penelitian ini peneliti memberikan perlakuan yang berupa model pembelajaran Discovery Learning berbasis kontekstual pada kelas $\mathrm{VII}_{\mathrm{B}}$ dan model pembelajaran Konvensional pada kelas VII $_{C}$. Instrumen yang digunakan adalah tes pemahaman konsep matematika yang berupa soal essay yang disusun sesuaai dengan indikator pencapaian kompetensi dan indikator pemahaman konsep. Data dalam penelitian ini berupa data skor pemahaman konsep matematika awal yang diperoleh melalui pretest, data skor pemahaman konsep matematika setelah pembelajaran yang diperoleh melalui posttest dan data skor peningkatan (gain) pemahaman konsep matematika.

Penskoran tes pemahaman konsep matematika siswa dinilai berdasarkan indikator pemahaman konsep. Adapun kriteria penilaian kemampuan pemahaman konsep dilihat pada tabel berikut:

Tabel 1. Pedoman penskoran tes pemahaman konsep matematika

\begin{tabular}{llll}
\hline $\begin{array}{l}\text { Indikator pemahaman } \\
\text { konsep }\end{array}$ & \multicolumn{1}{c}{ Keterangan } & Skor \\
\hline $\begin{array}{l}\text { Menyatakan } \\
\text { sebuah konsep }\end{array}$ & ulang & Jawaban kosong & 0 \\
& Tidak dapat menyatakan ulang konsep & 1 \\
\hline
\end{tabular}




\begin{tabular}{|c|c|c|}
\hline \multirow{8}{*}{$\begin{array}{l}\text { Memberikan contoh } \\
\text { dan ukan contoh dari } \\
\text { suatu konsep }\end{array}$} & Dapat menyatakan ulang konsep tetapi masih banyak kesalahan & 2 \\
\hline & Dapat menyatakan ulang konsep tetapi belum tepat & 3 \\
\hline & Dapat menyatakan ulang konsep dengan tepat & 4 \\
\hline & Jawaban kosong & 0 \\
\hline & Tidak dapat memberi contoh dan bukan contoh & 1 \\
\hline & Dapat memberikan contoh dan bukan contoh tetapi masih banyak kesalahan & 2 \\
\hline & Dapat memberikan contoh dan bukan contoh tetapi belum tepat & 3 \\
\hline & Dapat memberikan contoh dan bukan contoh dengan tepat & 4 \\
\hline \multirow{6}{*}{$\begin{array}{l}\text { Mengklasifikasi objek } \\
\text { menurut sifat-sifat } \\
\text { tertentu sesuai dengan } \\
\text { konsepnya }\end{array}$} & Jawaban kosong & 0 \\
\hline & Tidak dapat mengklasifikasikan objek sesuai dengan konsepnya & 1 \\
\hline & $\begin{array}{l}\text { Dapat mengklasifikasikan maupun menyebutkan sifat-sifat sesuai dengan } \\
\text { konsepnya tetapi masih banyak kesalahan }\end{array}$ & 2 \\
\hline & $\begin{array}{l}\text { Dapat mengklasifikasikan maupun menyebutkan sifat-sifat sesuai dengan } \\
\text { konsepnya tetapi belum tepat }\end{array}$ & 3 \\
\hline & $\begin{array}{l}\text { Dapat mengklasifikasikan maupun menyebutkan sifat-sifat sesuai dengan } \\
\text { konsepnya dengan tepat }\end{array}$ & 4 \\
\hline & Jawaban kosong & 0 \\
\hline \multirow{4}{*}{$\begin{array}{l}\text { Menyajikan konsep ke } \\
\text { dalam berbagai bentuk } \\
\text { representasi matematis }\end{array}$} & $\begin{array}{l}\text { Tidak dapat menyajikan sebuah konsep dalam satu bentuk representasi } \\
\text { matematika }\end{array}$ & 1 \\
\hline & $\begin{array}{l}\text { Dapat menyajikan sebuah konsep dalam satu bentuk representasi } \\
\text { matematika namun belum tepat }\end{array}$ & 2 \\
\hline & $\begin{array}{l}\text { Dapat menyajikan sebuah konsep dalam satu bentuk representasi } \\
\text { matematika dengan tepat }\end{array}$ & 3 \\
\hline & Dapat menyajikan sebuah konsep dalam lebih dari satu & 4 \\
\hline \multirow{6}{*}{$\begin{array}{l}\text { Mengembangkan } \\
\text { syarat perlu/ syarat } \\
\text { cukup suatu konsep }\end{array}$} & & 0 \\
\hline & Jawaban kosong & \\
\hline & Hanya dapat menentukan syarat perlu dari suatu konsep & 1 \\
\hline & Hanya dapat menentukan syarat cukup dari suatu konsep & 2 \\
\hline & Dapat menentukan syarat cukup dan syarat perlu suatu konsep & 3 \\
\hline & $\begin{array}{l}\text { Dapat menentukan syarat cukup dan syarat perlu suatu konsep disertai dengan } \\
\text { contoh-contoh }\end{array}$ & 4 \\
\hline \multirow{5}{*}{$\begin{array}{l}\text { Menggunakan, } \\
\text { memanfaatkan dan } \\
\text { memilih prosedur } \\
\text { atau operasi yang } \\
\text { perlu }\end{array}$} & Jawaban kosong & 0 \\
\hline & $\begin{array}{l}\text { Tidak dapat menggunakan, memanfaatkan, dan memilih prosedur atau } \\
\text { operasi }\end{array}$ & 1 \\
\hline & $\begin{array}{l}\text { Dapat menggunakan, memanfaatkan, dan memilih prosedur atau operasi } \\
\text { tetapi masih banyak kesalahan }\end{array}$ & 2 \\
\hline & $\begin{array}{l}\text { Dapat menggunakan, memanfaatkan, dan memilih prosedur atau operasi } \\
\text { tetapi belum tepat }\end{array}$ & 3 \\
\hline & $\begin{array}{l}\text { Dapat menggunakan, memanfaatkan, dan memilih prosedur atau operasi } \\
\text { dengan tepat }\end{array}$ & 4 \\
\hline \multirow{5}{*}{$\begin{array}{l}\text { Mengaplikasikan } \\
\text { konsep atau algoritma } \\
\text { dalam pemecahan } \\
\text { masalah }\end{array}$} & Jawaban kosong & 0 \\
\hline & $\begin{array}{l}\text { Tidak dapat mengaplikasikan rumus sesuai prosedur dalam } \\
\text { menyelesaikan soal pemecahan masalah }\end{array}$ & 1 \\
\hline & $\begin{array}{l}\text { Dapat mengaplikasikan rumus sesuai prosedur dalam menyelesaikan soal } \\
\text { pemecahan masalah tetapi masih banyak kesalahan }\end{array}$ & 2 \\
\hline & $\begin{array}{l}\text { Dapat mengaplikasikan rumus sesuai prosedur dalam menyelesaikan soal } \\
\text { pemecahan masalah tetapi ada kesalahan operasi }\end{array}$ & 3 \\
\hline & $\begin{array}{l}\text { Dapat mengaplikasikan rumus sesuai prosedur dalam menyelesaikan soal } \\
\text { pemecahan masalah dengan tepat }\end{array}$ & 4 \\
\hline
\end{tabular}

Adaptasi Kasum (Siti mawaddah dan Ratih maryanti, 2016)

Skor pemahaman konsep matematika siswa yang diperoleh kemudian diubah menjadi nilai dengan ketentuan: 


$$
\text { Nilai }=\frac{\text { skor pemahaman konsep siswa }}{\text { skor yang diharapkan }} \times 100
$$

Selanjutnya nilai rata-rata kemampuan pemahaman konsep matematika siswa diinterpretasikan menurut tabel berikut ini:

Tabel 2. kategorisasi skor pemahaman konsep matematika siswa

\begin{tabular}{ccc}
\hline No. & Nilai & Kriteria \\
\hline 1. & $85,00-100$ & Sangat Tinggi \\
2. & $70,00-84,99$ & Tinggi \\
3. & $55,00-69,99$ & Cukup Tinggi \\
4. & $40,00-54,99$ & Rendah \\
5. & $0,00-39,99$ & Sangat Rendah \\
\hline
\end{tabular}

Dalam penelitian ini pembelajaran dikatakan berpengaruh jika rata-rata kemampuan pemahaman konsep matematika siswa minimal dalam kategori tinggi (Skor $\geq 70$ ). Kemudian kemampuan pemahaman konsep matematika siswa pada kelas eksperimen serta peningkatannya lebih dari kemampuan pemahaman konsep matematika siswa pada kelas kontrol. Berdasarkan hal tersebut, maka hipotesis penelitian ini adalah sebagai berikut:

1) Hipotesis 1: Kemampuan pemahaman konsep siswa yang diajar dengan menggunakan model discovery learning berbasis kontekstual lebih dari atau samadengannilai 70,00.

2) Hipotesis 2: Kemampuan pemahaman konsep siswa yang diajar dengan model discovery learning berbasis kontekstual lebih dari kemampuan pemahaman konsep siswa yang diajar dengan model konvensional.

3) Hipotesis 3: Peningkatan kemampuan pemahaman konsep siswa yang diajar dengan model discovery learning berbasis kontekstual lebih dari peningkatan kemampuan pemahaman konsep siswa yang diajar dengan model konvensional.

\section{Hasil dan Pembahasan}

Hasil analisis deskriptif yang berkaitan dengan pemahaman konsep matematika siswa ditunjukkan dengan kemampuan siswa menyelesaikan tes pemahaman konsep matematika pada pokok bahasan Himpunan. Berikut disajikan statistik pemahaman konsep matematika siswa pada kelas eksperimen dan pada kelas kontrol sebelum diberikan perlakuan (Pretest).

Berdasarkan hasil penelitian maka secara deskriptif, hasil pretest dikelas eksperimen yang diajar dengan model Discovery Learning berbasis kontekstual bervariasi dengan rata-rata 52,68 yang jika dikategorikan kedalam skor pemahaman konsep matematika siswa berada pada interval 40,00-54,99 yang tergolong rendah. Sedangkan hasil pretest dikelas kontrol yang diajar dengan model pembelajaran konvensional bervariasi dengan rata-rata 55,00 yang jika dikategorikan berada pada interval 55,00-69,99 yang tergolong cukup tinggi. Berbeda dengan 
hasil pretest siswa, kemampuan pemahaman konsep matematika siswa setelah mengikuti pembelajaran (posttest) dikelas eksperimen yang diajar dengan model pembelajaran Discovery Learning berbasis kontekstual bervariasi dengan rata-rata 80,35 yang jika dikategorikan berada pada interval 70,00-84,99 yang tergolong tinggi. Hal ini menandakan bahwa kemampuan pemahaman konsep matematika siswa dikelas eksperimen setelah diajar dengan model Discovery Learning berbasis kontekstual mengalami peningkatan dari rata-rata pretest 52,68 menjadi 80,35 dan termasuk dalam kategori tinggi.

Sedangkan kemampuan pemahaman konsep matematika siswa setelah mengikuti pembelajaran (posttest) dikelas kontrol yang diajar dengan model konvensional bervariasi dengan rata-rata 62,03 yang jika dikategorikan berada pada interval 55,00-69,99 yang tergolong cukup tinggi. Hal ini menandakan bahwa kemampuan pemahaman konsep matematika siswa dikelas kontrol setelah diajar dengan model konvensional mengalami peningkatan dari rata-rata pretest 55,00 menjadi menjadi 62,03 dan termasuk dalam kategori cukup tinggi. Analisis skor gain ternormalisasi pada kelas eksperimen diperoleh bahwa sebanyak 11 orang siswa $(35,5 \%)$ yang memperoleh skor gain ternormalisasi pada kategori tinggi, 17 orang siswa $(54,8 \%)$ yang memperoleh skor pada kategori sedang, dan sebanyak 3 orang siswa $(9,7 \%)$ yang memperoleh skor pada kategori rendah. Berdasarkan hal tersebut dapat disimpulkan bahwa peningkatan kemampuan pemahaman konsep matematika siswa pada kelas eksperimen berada pada kategori sedang.

Analisis skor gain ternormalisasi pada kelas kontrol diperoleh bahwa sebanyak 23 orang siswa $(74,2 \%)$ yang memperoleh skor gain ternormalisasi pada kategori rendah, 8 orang siswa $(25,5 \%)$ yang memperoleh skor gain pada kategori sedang, dan tidak terdapat siswa yang memperoleh skor gain ternormalisasi pada kategori tinggi. Berdasarkan hal tersebut dapat disimpulkan bahwa peningkatan kemampuan pemahaman konsep matematika siswa pada kelas eksperimen berada pada kategori Rendah.

Berdasarkan analisis data inferensial dengan menggunakan uji-t satu sample (One Sample t-test)menggunakan windows SPSS maka hasilnya dapat dilihat pada Tabel 3. berikut:

Tabel 3. Pengujian hasil posttest pemahaman konsep matematika siswa dikelas eksperimen

\begin{tabular}{|c|c|c|c|c|c|c|c|c|}
\hline \multicolumn{9}{|c|}{ Test Value $=69.99$} \\
\hline & & \multirow[b]{2}{*}{$\mathrm{T}$} & \multirow[b]{2}{*}{ Df } & \multirow{2}{*}{$\begin{array}{l}\text { Sig. } \\
\text { tailed) }\end{array}$} & \multirow[t]{2}{*}{$(2-$} & \multirow{2}{*}{$\begin{array}{c}\text { Mean } \\
\text { Difference }\end{array}$} & \multicolumn{2}{|c|}{$\begin{array}{c}95 \% \text { Confidence Interval } \\
\text { of the Difference }\end{array}$} \\
\hline & & & & & & & Lower & Upper \\
\hline $\begin{array}{l}\text { posttest } \\
\text { eksperimen }\end{array}$ & kelas & 5,217 & 30 &, 000 & & 10,455 & 6,36 & 14,55 \\
\hline
\end{tabular}

Berdasarkan hasil analisis dengan menggunakan taraf signifikansi 5\% tampak bahwa 
nilai $\mathrm{p}$ (sig. $(2$-tailed) $)$ adalah $0,000<0,05$. Ini berarti $\mathrm{H}_{0}$ ditolak dan $\mathrm{H}_{1}$ diterima yakni ratarata kemampuan pemahaman konsep matematika siswa kelas $\mathrm{VII}_{\mathrm{B}} \mathrm{SMP}$ Negeri 2 Barombong setelah diajar menggunakan model Discovery Learning berbasis kontekstual lebih dari 69,99.

Tabel 4. Pengujian perbandingan hasil posttest pemahaman konsep matematika siswa antara kelas eksperimen dan kelas kontrol menggunakan independent t-test pada spss

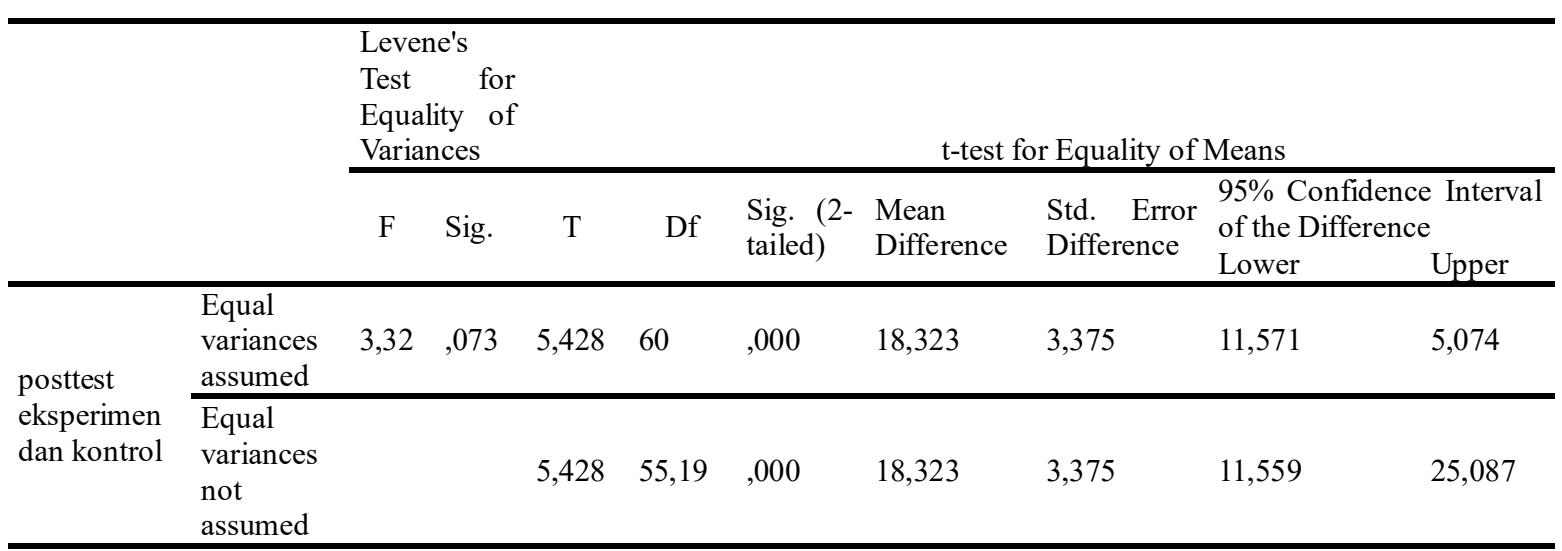

Berdasarkan Tabel 4, karena data posttest kelas eksperimen dan kelas kontrol telah melalui uji prasyarat zakni uji normalitas dan uji homogenitas dan hasilnya data memiliki varians yang sama, maka kita menggunakan equal variances assumed pada tabel. Diperoleh hasil analisis dengan menggunakan taraf signifikansi 5\% tampak bahwa nilai p (sig.(2-tailed)) adalah 0,000 $<0,05$. Ini berarti $\mathrm{H}_{0}$ ditolak dan $\mathrm{H}_{1}$ diterima yakni kemampuan pemahaman konsep matematika siswa kelas eksperimen setelah diajar menggunakan model Discovery Learning berbasis kontekstual lebih tinggi dibandingkan dengan kemampuan pemahaman konsep pada kelas kontrol yang diajar menggunakan model konvensional.

Tabel 5. Pengujian perbandingan Gain ternormalisasi kelas eksperimen dan kelas kontrol

\begin{tabular}{|c|c|c|c|c|c|c|c|c|c|c|}
\hline & & $\begin{array}{l}\text { Leve } \\
\text { Test } \\
\text { Equa } \\
\text { Varia } \\
\end{array}$ & $\begin{array}{l}\text { e's } \\
\text { for } \\
\text { ity of } \\
\text { ices }\end{array}$ & & & & t-test $\mathrm{f}$ & r Equality of $\mathrm{N}$ & Means & \\
\hline & & $\mathrm{F}$ & Sig. & $\mathrm{T}$ & Df & $\begin{array}{l}\text { Sig. (2- } \\
\text { tailed) }\end{array}$ & $\begin{array}{l}\text { Mean } \\
\text { Difference }\end{array}$ & $\begin{array}{l}\text { Std. Error } \\
\text { Difference }\end{array}$ & $\begin{array}{l}95 \% \text { Confidence I } \\
\text { the Difference } \\
\text { Lower }\end{array}$ & $\begin{array}{l}\text { Interval of } \\
\text { Upper } \\
\end{array}$ \\
\hline \multirow{2}{*}{$\begin{array}{l}\text { posttest } \\
\text { eksperim } \\
\text { en dan } \\
\text { kontrol }\end{array}$} & $\begin{array}{l}\text { Equal } \\
\text { variances } \\
\text { assumed } \\
\end{array}$ & 1,68 & ,200 & 5,761 & 60 &, 000 & ,47097 & ,08176 & ,30743 & ,63450 \\
\hline & $\begin{array}{l}\text { Equal } \\
\text { variances } \\
\text { not } \\
\text { assumed }\end{array}$ & & & 5,761 & 44,912 &, 000 & ,47097 & ,08176 & ,30630 & ,63564 \\
\hline
\end{tabular}

Berdasarkan Tabel 5, karena data $N$-Gain kelas eksperimen dan kelas kontrol memiliki varians yang sama, maka kita menggunakan equal variances assumed pada tabel. Diperoleh hasil analisis dengan menggunakan taraf signifikansi 5\% tampak bahwa nilai p (sig.(2-tailed)) 
adalah $0,000<0,05$. Ini berarti $\mathrm{H}_{0}$ ditolak dan $\mathrm{H}_{1}$ diterima yakni peningkatan kemampuan pemahaman konsep matematika siswa kelas eksperimen setelah diajar menggunakan model Discovery Learning berbasis kontekstual lebih dari peningkatan kemampuan pemahaman konsep pada kelas kontrol yang diajar menggunakan model konvensional.

Adanya perbedaan ini dapat pula dilihat selama proses pembelajaran. Dimana siswa pada kelas eksperimen lebih aktif bekerja sama dengan anggota kelompoknya dalam memecahkan masalah pada LKPD, masing-masing kelompok pok saling berlomba memecahkan masalah dalam LKPD karena kelompok yang paling pertama selesai akan mendapatkan reward. Siswa sesekali meminta bantuan dari guru dengan cara bertanya apabila merasa kebingungan dalam proses pemecahan masalah. Hal ini dapat menimbulkan terjadinya interaksi dalam proses pembelajaran baik interaksi antar teman maupun kepada guru, yang secara tidak langsung juga dapat meningkatkan social skill siswa. Dengan penggunaan model pembelajaran Discovery Learning berbasis kontekstual ini, memungkinkan siswa belajar lebih aktif, konstruksi pengetahuan akan menjadi lebih besar serta pemahaman siswa akan tertanam dalam benak siswa dalam jangka waktu yang relatif lama. Seperti yang dikemukakan Wilcox dalam Hosnan (2014: 281) bahwa dalam pembelajaran dengan penemuan, siswa didorong untuk belajar sebagian besar melalui keterlibatan aktif mereka sendiri dengan konsep-konsep dan prinsipprinsip dan guru mendorong siswa untuk memiliki pengalaman dan melakukan percobaan yang memungkinkan mereka menemukan prinsip untuk diri mereka sendiri.

Pembelajaran matematika dikelas kontrol yang diterapkan model konvensional terlihat antusias beberapa siswa saat belajar matematika, siswa duduk tidak secara berkelompok dan kelas cenderung tenang. Namun, Siswa terlihat pasif saat pembelajaran berlangsung, Siswa mendengarkan dan sekali-kali mencatat penjelasan penting dari guru. Terlihat Sebagian besar siswa yang duduk dibagian belakang tidak fokus mendengarkan materi yang disampaikan, hanya siswa yang duduk dibangku dibagian depan saja yang sangat fokus mendengarkan penyampaian materi dari guru dan sesekali bertanya. Beberapa siswa lainnya juga terlihat menghayal dan mengantuk mengingat pembelajaran berlangsung disiang hari.

Perbedaan rata-rata gain ternormalisasi antara kelas eksperimen yang diajar dengan model Discovery Learning berbasis kontekstual dan kelas kontrol yang diajar dengan model konvensional menunjukkan bahwa kemampuan pemahaman konsep matematika siswa yang diajar dengan model Discovery Learning berbasis kontekstual lebih tinggi dari pada siswa yang diajar dengan model konvensional. Terlihat bahwa rata-rata kemampuan pemahaman konsep siswa pada kelas eksperimen yang diajar dengan model pembelajaran Discovery Learning berbasis kontekstual minimal berada pada kategori tinggi $(\geq 70,00)$, dan kemampuan 
pemahaman konsep matematika siswa dikelas eksperimen yang diajar dengan model pembelajaran Discovery Learning berbasis kontekstual serta peningkatannya lebih dari kemampuan pemahaman konsep matematika siswa dikelas kontrol yang diajar dengan model konvensional, maka dapat disimpulkan bahwa model pembelajaran Discovery Learning berbasis kontekstual berpengaruh terhadap kemampuan pemahaman konsep matematika siswa kelas VII SMP Negeri 2 Barombong.

\section{Kesimpulan dan Saran}

Berdasarkan hasil penelitian yang telah diuraikan maka diperoleh kesimpulan model Discovery Learning berbasis kontekstual berrpengaruh terhadap pemahaman konsep matematika siswa kelas VII SMP Negeri 2 Barombong.

1. Kemampuan pemahaman konsep matematika siswa kelas VII $\mathrm{B}_{\mathrm{B}} \mathrm{SMP}$ Negeri 2 Barombong yang diajar dengan model Discovery Learning berbasis kontekstual berada pada kategori Tinggi dengan nilai rata-rata sebesar 80,35. Nilai minimum yang diperoleh siswa adalah 53 sedangkan Nilai maksimum yang di peroleh siswa adalah 98.

2. Kemampuan pemahaman konsep matematika siswa kelas $\mathrm{VII}_{\mathrm{C}}$ SMP Negeri 2 Barombong yang diajar dengan model konvensional berada pada kategori Cukup tinggi dengan nilai rata-rata sebesar 62,03. Nilai minimum yang diperoleh siswa adalah 33 sedangkan Nilai maksimum yang di peroleh siswa adalah 85 .

3. Kemampuan pemahaman konsep matematika siswa yang diajar dengan menggunakan model Discovery Learning berbasis kontekstual lebih dari atau sama dengan nilai 70,00 yang dilihat dari hasil analisis inferensial yang menggunakan uji t (one Sample t-test) pada data posttest kelas eksperimen.

4. Pada analisis secara inferensial menggunakan uji $\mathrm{t}$ (Independent Sample t-test) terhadap data posttest pada kelas eksperimen dan kelas kontrol, diperoleh hasil bahwa kemampuan pemahaman konsep matematika siswa pada kelas eksperimen yang diajar dengan model discovery learning berbasis kontekstual lebih dari kemampuan pemahaman konsep siswa pada kelas kontrol yang diajar dengan model konvensional.

5. Pada analisis secara inferensial menggunakan uji t (Independent Sample t-test) terhadap $N$ Gain pada kedua kelas, hasilnya menunjukkan bahwa peningkatan kemampuan pemahaman konsep matematika siswa yang diajar dengan model discovery learning berbasis kontekstual lebih dari peningkatan kemampuan pemahaman konsep siswa yang diajar dengan model konvensional. 
6. Terdapat pengaruh penerapan model discovery learning berbasis kontekstual terhadap kemampuan pemahaman konsep matematika siswa kelas VII SMP Negeri 2 Barombong.

\section{DAFTAR PUSTAKA}

BSNP. (2016). Permendikbud No. 23 Tahun 2016 tentang Standar Isi untuk Satuan Pendidikan Dasar dan Menengah. Kemendikbud. Jakarta.

Daryanto \& Muljo, R. (2012). Model Pembelajaran Inovatif. Yogyakarta: Gala Media.

Hosnan, M. (2014). Pendekatan Saintifik dan Kontekstual dalam Pembelajaran Abad 21. Ghalia Indonesia, Bogor.

Iriana, D. (2008). Penerapan Metode Penemuan Terbimbing Dalam Pembelajaran Matematika untuk Meningkatkan Kemampuan Berpikir Logis Siswa SMP. Skripsi pada FMIPA UPI.

Kemendikbud. (2013). Materi Pelatihan Guru: implemetasi kurikulum 2013. Jakarta: Kementrian Pendidikan dan Kebudayaan.

Komalasari, K. 2010. Pembelajaran Kontekstual: Konsep dan Aplikasi. Bandung: Refika Aditama.

Kurniasih \& Sani. (2014). Langkah-langkah Discovery Learning. https://www.scribd.com/doc/315886198/Gabungan-Model-Pembelajaran-DiscoveryLearning. Diakses pada 11/01/2019

Nila, K . (2008). Pemahaman Konsep Matematik Dalam Pembelajaran Matematika. Inprosiding Seminar Nasional Matematika Dan Pendidikan Matematika. Jurusan Pendidikan Matematika Dan Ilmu Pengetahuan Alam. Universitas Negeri Yogyakarta.

Sani, R. A. (2014). Pembelajaran Saintifik untuk kurikulum 2013. Jakarta: Bumi Aksara.

Setiawan, W. (2017). kemampuan pemahaman konsep matematis siswa SMP dalam pembelajaran menggunakan model Discovery Learning.

Siti, M \& Ratih, M. (2016). Kemampuan pemahaman konsep matematis siswa SMP dalam pembelajaran menggunakan model penemuan terbimbing (Discovery Learning). EDUMAT Jurnal Pendidikan Matematika. Vol 4 No. 1. Hal 76-85

Tim Pustaka Yustisia. (2007). Panduan Lengkap KTSP. Yogyakarta: Pustaka Yustisia.

Trianto. (2008). Mendesain Pembelajaran Kontekstual (Contextual Teaching and Learning) di Kelas.Surabaya: Cerdas Pustaka.

Yahya, Yusuf. Dkk. (2010). Matematika Dasar Perguruan Tinggi. Bogor. Ghalia Indonesia.

Yamin. 2013. Paradigma Baru Pembelajaran. Jakarta : Referensi. 